\title{
PENGEMBANGAN BUKU BERBASIS ENSIKLOPEDIA UNTUK MATA KULIAH BUDAYA INDONESIA PROGRAM DARMASISWA
}

\author{
Hermanto $^{1)^{*}}$, Sudaryanto ${ }^{2),}$ Cindy Febriana ${ }^{3),}$ \\ 1) ,2), dan 3) PBSI , FKIP, UAD, Jl. Ringroad Selatan, Kragilan, Tamanan, Kec. Banguntapan, \\ Bantul, Daerah Istimewa Yogyakarta 55191 \\ hermanto@pbsi.uad.ac.id., \\ sudaryanto@pbsi.uad.ac.id., \\ cindy.febryana.12@gmail.com
}

\begin{abstract}
ABSTRAK
Minat mahasiswa asing untuk belajar bahasa Indonesia sampai saat ini terus berkembang, sehingga menjadi peluang dan tantangan bagi pengelola lembaga pendidikan. Hal tersebut tentu berdampak pada kebutuhan materi ajar. Penelitian ini mencoba untuk mengembangkan materi ajar berbasis ensiklopedia tentang info fakta unik dan budaya Indonesia. Tujuan penelitian ini adalah untuk mendeskripsikan proses pengembangan buku ensiklopedia bagi mahasiswa asing program darmasiswa di Universitas Ahmad Dahlan. Jenis penelitian yang digunakan adalah jenis penelitian pengembangan model ADDIE yang dikembangkan oleh Dick dan Carry. Tahapan ADDIE tersebut adalah; Analysis, Design, Development, Implementation, dan Evaluation. Data diperoleh melalui wawancara, observasi, validasi produk oleh ahli, dan uji coba terhadap mahasiswa program darmasiswa. Namun pada tahun pertama penelitian ini fokus pada tahapan pengembangan buku ensiklopedia. Data hasil wawancara dianalisis dengan teknik analisis kualitatif. Data hasil validasi produk dan hasil penilaian uji coba menggunakan deskriptif kuantitatif. Hasil penelitian menunjukkan bahwa jenis buku ensiklopedia yang berisi info fakta unik Indonesia dan budaya Indonesia tepat untuk dikembangkan, karena belum ada buku yang secara khusus menginformasikan hal itu untuk mahasiswa asing. Rancangan buku 99 fakta unik Indonesia dan budaya Indonesia diperoleh dari berbagai sumber reverensi yang relevan. Selanjutnya adalah pengembangan produk buku dengan judul 99 Fakta Unik dan Budaya Indonesia bekerja sama dengan penerbit K-Media. Harapan selanjutnya adalah buku tersebut mampu menjadi buku reverensi yang berkualitas bagi pemelajar asing pada umumnya dan mahasiswa darmasiswa pada khususnya.
\end{abstract}

Kata kunci: Ensiklopedia, unik, budaya, dan BIPA. 


\section{PENDAHULUAN}

$\mathrm{P}$ rogram peminatan Bahasa Indonesia bagi Penutur Asing (BIPA) terus berkembang. Berdasarkan hasil kajian yang ditulis oleh Muliastuti (2017) menyebutkan bahwa sampai pada tahun 2008 sudah mencapai 2.037 dari 85 negara. Peningkatan peminat terus terjadi seperti tercermin dari data Biro Perencanaan Kerja Sama Luar Negeri (BPKLN) Kementerian Pendidikan dan Kebudayaan (Kemendikbud), hingga tahun 2013 total yang mengikuti program Darmasiswa sejak 1974 berjumlah 4.563 orang yang berasal dari 97 negara. Sampai 2017 tercatat setiap tahun yang mengikuti program Darmasiswa rata-rata diikuti sebanyak $700-800$ orang. Mereka belajar pada 54 universitas di Indonesia dan jumlahnya meningkat menjadi 111 negara.

Program Darmasiswa merupakan bentuk kegiatan perkulihan selama satu tahun atau dua semester mahasiswa asing belajar bahasa Indonesia di berbagai perguruan tinggi yang sudah dipetakan oleh pemerintah. Selain pembelajaran BIPA di dalam negeri (Indonesia), pembelajaran BIPA juga terlaksana di luar negeri. Sebagaimana dikemukakan oleh Wahya (dalam Muliastuti, 2017: 3) diperkirakan sebanyak 219 lembaga perguruan tinggi atau lembaga pendidikan di 74 negara. Tentunya sampai 2019 ini pembelajaran BIPA semakin berkembang.

Mencermati hal tersebut, di samping sebagai peluang, sekaligus menjadi tuntutan untuk menyiapkan segala bentuk terkait dengan persiapan, proses, dan sistem evaluasi yang menyeluruh. Persipan menyangkut ketersediaan bahan ajar, media pembelajaran, metode yang digunakan, silabus, dan Rencana Pelaksanaan Pembelajaran (RPP). Proses menyangkut bagaimana implementasi dari perencanaan yang sudah dibuat. Terakhir adalah sistem evaluasi berkelanjutan yang digunakan.

Muliastuti (2017: 3) menambahkan bahwa pengajaran BIPA sebagai salah satu langkah strategis dalam dalam mengimplementasi "Politik Bahasa Nasional". yang di dalam pengajaran BIPA menyangkut bagaimana pengembangan kurikulum, pengembangan bahan ajar yang sesuai dengan kebutuhan siswa dan perkembangan metodologi pengajaran BIPA, pengembangan tenaga kependidikan kebahasaan yang profesional, dan terakhir pengembangan sarana pendidikan bahasa yang memadai, terutama sarana uji kemahiran bahasa. Aspek-aspek itulah menjadi kegiatan dan aspek utama dalam penyajian implementasi politik bahasa nasional lewat ke-BIPA-an.

Sejauh pengamatan yang dilakukan di beberapa universitas yang ada di Indonesia, sebagain besar sudah menggunakan bahan ajar yang diterbitkan Badan Bahasa. Buku tersebut memiliki judul Lentera 1 untuk siswa BIPA tingkat dasar, Lentera 2 untuk siswa BIPA tingkat madya, dan Lentera 3 untuk siswa BIPA tingkat lanjut. Baru pada 2015 diterbitkan buku baru dengan judul Sahabatku Indonesia sebanyak enam jilid. Buku Sahabatku Indonesia sudah memenuhi enam jenjang kompetensi siswa BIPA. Keenam jenjang tersebut adalah A1 dan A2 untuk siswa tingkat pemula, B1 dan B2 untuk siswa tingkat madya, dan C1 dan C2 untuk siswa tingkat lanjut. Berdasarkan pengamatan selama tiga tahun terakhir, buku tersebut sudah menggunakan sistem pengembangan bahan ajar yang sesuai dengan kebutuhan siswa. Hal ini seperti diuraikan oleh Suyitno (2005) bahwa 
Hermanto $^{1)^{*}}$, Sudaryanto ${ }^{2),}$ dan Cindy Febriana ${ }^{3),}$ : Pengembangan Buku Berbasis

Ensiklopedia untuk Mata Kuliah Budaya Indonesia Program Darmasiswa

Website:https://jurnal.umj.ac.id/index.php/penaliterasi Email:penaliterasi@umj.ac.id

pengembangan bahan ajar BIPA hendaknya

disesuikan dengan kebutuhan dan hasil analisis kebutuhan belajar BIPA.

Sejalan dengan Suyitno (2005), terkait dengan kesesuian bahan ajar yang mempertimbangkan kebutuhan pemelajar itu sendiri adalah hasil penelitian dari Siroj (2015) dan Prasetiyo (2007) yang megungkapkan bahwa ketika akan mengembangkan bahan ajar hendaknya menganalisis dari aspek kebutuhan dan aspek budaya yang dimunculkan. Adanya integrasi tersebut diharapkan selain sebagai bahan ajar, juga dapat digunakan sebagai cara menginformasikan aspek budaya yang mendampingi bahasa Indonesia dituturkan dan dituliskan. Karena pada hakikatnya bahasa sebagai kebutuhan tidak terlepas dari aspek budaya yang muncul.

Program Darmasiswa yang dikelola oleh Kantor Urusan Internasional (KUI) Universitas Ahmad Dahlan (UAD) sudah mengelola mahasiswa Darmasiswa di tahun kelima sejak adanya program Darmasiswa dari PPSDK Kemendikbud. Buku pegangan yang digunakan adalah Lentera Indonesia, Sahabatku Indonesia, dan Sahabatku Indonesia Edisi Revisi 2017. Buku-buku tersebut tentunya sudah mencakup empat keterampilan berbahasa dan tata bahasa, yang menjadi sub-sub mata kuliah yang diberikan. Mata kuliah tersebut adalah menyimak, berbicara, membaca, menulis, tata bahasa, budaya Indonesia, memasak, seni musik, dan mata kuliah drama. Materimateri yang tertuang di dalam buku paket Sahabatku Indonesia edisi 2017 memiliki keunggulan dan kelemahan.

Keunggulannya adalah sudah sesuai dengan silabus yang dimunculkan dan aspek kegrafisan sudah bagus dan menarik. Sisi kelemahannya adalah pada bagian materi budaya Indonesia masih sebatas pada nukilan kecil pada setiap akhir bab, dan porsinya sedikit dalam hal menginformasikan Indonesia. Atas dasar itulah kemudian dibuat buku yang di dalamnya memuat informasi yang luas tentang budaya dan tentang Indonesia. Buku tersebut memiliki konsep seperti buku Ensiklopedi yang memilki letak keunggulan yaitu adanya info dan gambar pendukung. Harapan akhir yang didapatkan adalah mahasiswa asing mampu mengetahui tentang Indonesia berdasarkan budaya dan info berupa fakta terbaru tentang negara Indonesia.

Penelitian tahun pertama ini fokus pada analisis kebutuhan produk, perancangan produk, dan pengembangan produk. Sedangkan pada tahun kedua memuat kelayakan buku Ensikopedia dengan judul 99 Fakta Budaya Indonesia.

Materi ajar memiliki beberapa definisi. Menurut Harwood (2010) materi ajar adalah teks dan tugas-tugas belajar yang disajikan kepada peserta didik baik berbasis kertas, audio, atau visual. Sedangkan Brown (1995) menyampaikan bahwa semua deskripsi yang sistematik dari teknik dan latihan di dalam kelas dapat dikatakan sebagai materi ajar. Berdasarkan kedua definisi tersebut, dapat disimpulkan bahwa materi ajar adalah sebuah perangkat materi baik yang skalanya besar atau kecil, diterbitkan dengan skala terbatas atau diterbitkan oleh penerbit besar yang digunakan untuk mengajar. Kalau dilihat dari kedua definisi tersebut sudah jelas, artinya ada sisi fleksibel di dalam pengembangan materi. Muaranya adalah bagaimana kompetensi dasar dan tambahan mampu dicapai oleh peserta didik.

Dalam pengembangan materi ajar, Kusmiatun (2015: 69) mengemukakan bahwa kreativitas menjadi sebuah tuntutan bagi seorang pengajar BIPA. Pengajar BIPA 
Hermanto $^{1)^{*}}$, Sudaryanto ${ }^{2),}$ dan Cindy Febriana ${ }^{3),}$ : Pengembangan Buku Berbasis Ensiklopedia untuk Mata Kuliah Budaya Indonesia Program Darmasiswa Website:https://jurnal.umj.ac.id/index.php/penaliterasi Email:penaliterasi@umj.ac.id

hendaknya jangan terpaku pada satu sumber materi ajar saja. Perlu penguatan sumber ajar lain yang disebut materi tambahan atau suplemen. Adanya materi tambahan ini membuat pembelajaran BIPA lebih kaya.

Menurut Mulyana (2003: 42) pengembangan materi ajar adalah kegiatan yang diawali dari penelitian untuk mendapatkan gambaran tentang dokumen materi ajar bahasa dan pembelajarannya serta kebutuhan para siswa, dan dilanjutkan dengan kegiatan pengembangan materi ajar melalui uji coba yang berterima dan objektif. Kegiatan dilakukan dengan rancangan yang dapat menghasilkan materi yang efektif dari segi pengetahuan kebahasaan dan keterampilan berbahasa. Kemdiknas (2008) menyatakan bahwa pengembangan materi ajar dimulai dari standar kompetensi, kompetensi dasar, indikator, materi pembelajaran, kegiatan pembelajaran, dan materi ajar. Hal ini dapat digambarkan bahwa alur terakhir dalam pengembangan materi ajar adalah yang terakhir. Kesesuaian ini menjadi dasar yang kuat untuk menghasilkan produk materi ajar yang berkualitas.

Pengembangan materi ajar menentukan kreativitas seorang pengajar, untuk itu perlu adanya kesesuaian antara indikator dengan materi ajar yang dikembangkan. Sehingga muncul prinsip dalam pengembangan materi ajar. Suharsono (2013) menyatakan prinsip tersebut adalah materi yang tepat guna atau fungsional, pendekatan pembelajaran yang komunikatif dan integratif, pertimbangan level pembelajarnya, pemilihan berdasar sudut retensi atau kemampuan ingatan, dan visualisasi dalam materi. Menurut Suyitno (2005: 56) pada hakikatnya adalah sarana yang digunakan untuk membelajarkan pelajar BIPA yang secara langsung diolah dan dipahami secara sadar untuk mencapai tujuan pembelajaran yang telah ditetapkan. Secara sederhana, materi pembelajaran dapat diartikan sebagai bahan yang dipelajari oleh pelajar dalam upaya pencapaian tujuan pembelajaran. Melalui materi pembelajaran tersebuut, pelajar dituntut untuk melakukan sesuatu terhadapnya dengan jenis perilaku tertentu.

Alwi (2008) menyebutkan bahwa ensiklopedia adalah buku (serangkaian buku) yang menghimpun keterangan atau uraian tentang berbagai hal dalam bidang seni dan ilmu pengetahuan yang disusun menurut abjad atau lingkungan ilmu. Sedangkan menurut Chaer (2007) ensiklopedia adalah jenis kamus yang selain memberikan keterangan makna kata, juga memuat keterangan sesuatu.

Berdasarkan pengertian di atas dapat disimpulkan bahwa materi ajar berbasis ensiklopedia adalah sekumpulan materi yang isinya berupa informasi-informasi penting yang bersifat visual untuk memudahkan siswa dalam memperoleh informasi berupa keterangan dari visual yang dimunculkan.

\section{METODE PENELITIAN}

$\mathrm{P}$ enelitian ini adalah jenis penelitian pengembangan. Adapun yang akan dikembangkan dalam penelitian ini adalah pengembangan materi ajar berupa buku berbasis ensiklopedia untuk mata kuliah Budaya Indonesia Program Darmasiswa UAD. Model yang digunakan adalah model ADDIE, yaitu Analysis, Design, Development or Production, Impelemntation or Delivery, and Evaluation. Model ADDIE ini dikembangkan oleh Dick and Carry (Mulyatiningsih, 2011: 200) untuk merancang sistem pembelajaran. 


\section{HASIL DAN PEMBAHASAN}

$\mathrm{D}$ ata uji coba dalam penelitian pengembangan buku berbasis ensiklopedia untuk mata kuliah budaya Indonesia program darmasiswa yang diperoleh dengan pengembangan Research and Development (R\&D). Penelitian ini mengacu pada tahapan penelitian dan pengembangan model ADDIE (Analysis, Design, Development, Implementation, Evaluation) yang dikembangkan oleh Dick and Carry. Langkah-langkah atau tahapan pengembangan dan uji coba pemakaian lebih sederhana dan dengan waktu yang relatif singkat.

Data hasil penelitian ini adalah data kualitatif dan data kuantitatif yang didapat dari keseluruhan proses penelitian. Data kualitatif didapat dari masukan berupa saran dan kritikan dari pakar ahli. Data kuantitatif adalah data dari hasil validasi media, validasi bahasa, validasi materi, dan instrumen respon pemelajar BIPA. Instrumen yang digunakan untuk mengambil data adalah angket. Angket penilaian validator diperkuat dengan saran dan komentar sebagai pendukung. Data yang diperoleh berupa data kuantitatif yang kemudian dikategorikan dalam bentuk data kualitatif.

Adapun langkah-langkah penelitian dan pengembangan buku berbasis ensiklopedia untuk mata kuliah budaya Indonesia program darmasiswa adalah sebagai berikut.

\section{Deskripsi Hasil Tahap Analisis}

Untuk memperoleh informasi lebih dalam pada sebelum perancangan produk adalah melakukan analisis kebutuhan produk buku ensiklopedia yang berisikan informasi berupa fakta unik budaya Indonesia.
Tahapan ini bertujuan untuk mengetahui sejauh mana referensi yang ada tentang hal di atas. Sehingga dengan adanya analisis kebutuhan produk tersebut menjadi landasan kuat untuk mengembangan buku berbasis ensiklopedia untuk mahasiswa asing. Berikut adalah hasil dari analisis yang telah dilakukan.

a. Wawancara

Untuk memperoleh informasi lebih dalam mengenai ketersediaan, kebutuhan, dan proses pembelajaran BIPA dalam hal buku ajar. Wawancara menjadi pilihan awal tentang hal tersebut. Beberapa pengajar darmasiswa di lingkungan UAD menjadi sumber informasi awal. Narasumber yang menjadi subjek dalam penelitian ini adalah Ibu Desi Kamilasari, Bp. Galuh, Ibu Ina Ruslina, dan Ibu Alif. Hasil yang diperoleh adalah belum adanya buku khusus yang diperuntukan untuk mahasiswa BIPA dalam materi fakta-fakta unik budaya Indonesia.

Berdasarkan hasil wawancara tersebut dapat disimpulkan bahwa dengan terbitnya buku 99 Fakta Unik Budaya Indonesia sangat tepat untuk segera dikembangkan menjadi buku reverensi bagi pemelajar BIPA. Adapun kompetensi yang dimunculkan adalah keterampilan membaca. Indikatornya adalah pemelajar mampu menggali informasi tentang budaya Indonesia. Buku ini diperuntukkan minimal bagi pemelajar asing tingkat madya atau B1. Sesuai dengan kompetensi kebahasaan membaca dengan kode B2.4 menjelaskan keberagaman pariwisata yang ada di Indonesia melalui kegiatan membaca dan B2.5 menjelaskan beberapa tempat bersejarah yang ada di Indonesia melalui keterampilan membaca.

b. Observasi Lapangan

Observasi di lapangan bertujuan untuk memperoleh lebih lanjut tentang kebutuhan 
Hermanto $^{1)^{*}}$, Sudaryanto ${ }^{2),}$ dan Cindy Febriana ${ }^{3),}$ : Pengembangan Buku Berbasis Ensiklopedia untuk Mata Kuliah Budaya Indonesia Program Darmasiswa Website:https://jurnal.umj.ac.id/index.php/penaliterasi Email:penaliterasi@umj.ac.id

produk sebelum dikembangkan. Observasi

dilakukan pada kelas membaca yang diampu oleh Ibu Desi Kamilawati, S.S., M.A. pada 16 Juli 2019 di kelas Darmasiswa.

c. Analisis Dokumen

Analisis dokumen digunakan untuk menambah data need assessment atau analisis kebutuhan produk yang akan dikembangkan. Teknik ini menjadi teknik terakhir dalam pengumpulan data kebutuhan awal. Berdasarkan hasil pengamatan dan dokumentasi dari tahun-tahun sebelumnya diperoleh bahwa selama ini pengajar BIPA program Darmasiswa UAD memanfaatkan buku Sahabatku Indonesia sebagai reverensi utama. Selain itu, buku Lentera Indonesia dan Sahabatku Indonesia untuk Anak SD juga digunakan. Namun belum ada yang menggunakan semacam buku ensiklopedi Indonesia.

\section{Deskripsi Tahap Desain}

Tahapan dalam mendesain buku ensiklopedia 99 Fakta Unik Budaya Indonesia adalah sebagai berikut.

$\begin{array}{llrr}\text { a. } & \text { Menyusun } & \text { sistematika } & \text { buku } \\ \text { ensiklopedia } & 99 \quad \text { Fakta } & \text { Budaya } \\ & \text { Indonesia } \\ & & & \end{array}$

1) Cover

2) Daftar isi

3) Kata pengantar

4) Isi buku berupa 99 fakta unik budaya Indonesia

5) Daftar pustaka

6) Daftar gambar

7) Biodata penyusun

b. Pengumpulan Bahan

Pengumpulan bahan merupakan tahap yang tidak kalah penting dengan tahapan yang lain. Tahapan ini berisi kegiatan mengumpulkan sumber informasi tentang fakta-fakta unik budaya Indonesia dari buku, majalah, koran, instagram, dan gambar pendukung. Tahap selanjutnya adalah menentukan jenis kertas yang akan digunakan dalam penyusunan buku. Peneliti memilih kertas berukuran A4 (210x297 mm) dengan ketentuan A4 160 gr untuk sampul buku 99 fakta unik budaya Indonesia dan A4 80 gr untuk isi dari buku tersebut.

\section{Deskripsi Hasil Tahap Pengembangan}

Desain buku 99 Fakta Budaya Indonesia yang menarik secara visual diharapkan dapat memotivasi pemelajar BIPA dalam mengikuti pembelajaran bahasa Indonesia dan mampu menumbuhkan rasa senang untuk mempelajari bahasa Indoensia. Langkah selanjutnya setelah melakukan penyusunan buku 99 Fakta Budaya Indonesia, kemudian dikonsultasikan dengan tim peneliti, dalam hal ini Bp. Sudaryanto, M.Pd. dan mahasiswa yang menjadi tim dalam penelitian ini. Berikut halaman depan buku 99 Fakta Budaya Indonesia.

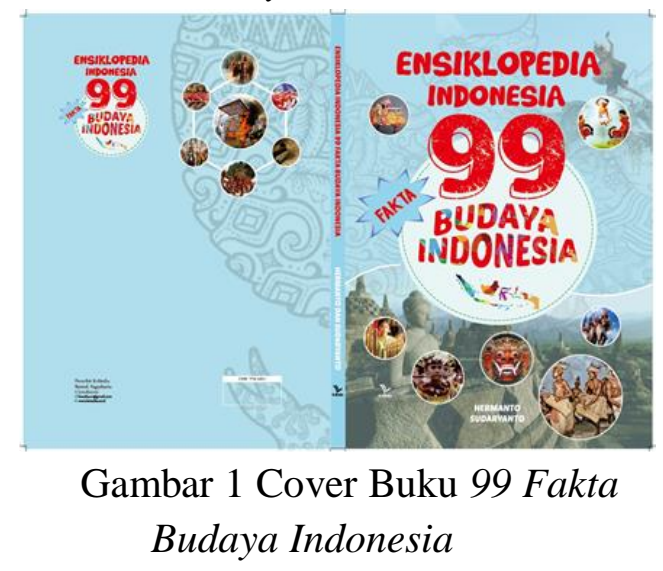

Untuk data berupa 99 fakta budaya Indonesia dapat dilihat pada lampiran 10 laporan penelitian ini. Tahap selanjutnya adalah uji validasi materi dan uji pemakaian terhadap ahli materi, ahli bahan ajar, dan pengguna.

a. Data Hasil Validasi Ahli Materi

Validasi ahli materi rencananya akan dilaksanakan pada tahun kedua, sekitar bulan Maret 2020 oleh ahli materi Ibu Dessy Kamilasari, SS., M.A. Data hasil validasi oleh ahli materi meliputi aspek kelayakan 
Hermanto $^{1)^{*}}$, Sudaryanto ${ }^{2),}$ dan Cindy Febriana ${ }^{3),}$ : Pengembangan Buku Berbasis

Ensiklopedia untuk Mata Kuliah Budaya Indonesia Program Darmasiswa

Website:https://jurnal.umj.ac.id/index.php/penaliterasi Email:penaliterasi@umj.ac.id

isi, aspek kelayakan bahasa, aspek kelayakan penyajian, dan aspek kelayakan kegrafikan. Validasi ahli materi dilakukan satu kali yaitu penilaian produk secara keseluruhan. Penilaian materi ini menggunakan skala likert dengan rentang nilai sebagai berikut: 1 = Sangat Kurang Baik, 2 = Kurang Baik, 3 = Cukup Baik, 4 = Baik, dan 5 = Sangat Baik.

b. Data Hasil Validasi Ahli Bahan Ajar

Validasi ahli bahan ajar rencananya akan dilaksanakan pada tahun kedua, sekitar bulan Maret 2020 oleh ahli bahan ajar Dra. Triwati Rahayu, M.Hum. Data hasil validasi oleh ahli bahan ajar meliputi aspek kelayakan isi, aspek kelayakan bahasa, aspek kelayakan penyajian, dan aspek kelayakan kegrafikan. Validasi ahli bahan ajar dilakukan satu kali yaitu penilaian produk secara keseluruhan. Penilaian materi ini menggunakan skala likert dengan rentang nilai sebagai berikut: 1 = Sangat Kurang Baik, 2 = Kurang Baik, $3=$ Cukup Baik, 4 = Baik, dan 5 = Sangat Baik.

c. Data Hasil Validasi Pengguna

Validasi ahli materi rencananya akan dilaksanakan pada tahun kedua, sekitar bulan Maret 2020 oleh pengguna Bapak Galuh, SS., M.A. dan mahasiswa program Darmasiswa. Data hasil validasi oleh pengguna meliputi aspek kelayakan isi, aspek kelayakan bahasa, aspek kelayakan penyajian, dan aspek kelayakan kegrafikan. Validasi pengguna dilakukan satu kali yaitu penilaian produk secara keseluruhan. Penilaian pengguna ini menggunakan skala likert dengan rentang nilai sebagai berikut: 1 = Sangat Kurang Baik, 2 = Kurang Baik, 3 = Cukup Baik, 4 = Baik, dan 5 = Sangat Baik.

4. Deskripsi Hasil Tahap Implementasi

Pada tahap implementasi yang rencananya akan dilakukan terbatas pada satu kelas Darmasiswa Universitas Ahmad Dahlan (UAD) yaitu kelas mata kuliah
Budaya Indonesia periode atau tahun ajaran 2019/2020. Rencana kegiatan pada tahap implementasi dengan mengenalkan buku suplemen 99 Fakta Budaya Indonesia sekaligus menyampaikan materi kepada pemelajar BIPA. Teknik yang dilakukan ini bertujuan untuk mendapatkan masukan dan saran secara langsung dari pemelajar BIPA yang telah mengikuti proses pembelajaran. Implementasi yang akan dilakukan di kelas mata kuliah Budaya Indonesia dengan jumlah 10 mahasiswa.

5. Deskripsi Hasil Tahap Evaluasi

Tahapan selanjutnya yang akan dilakukan adalah evaluasi. Tahapan evaluasi merupakan tahapan terakhir dilakukan dengan cara melihat hasil penilaian dari mahasiswa sebagai pengguna. Hasil penilaian mahasiswa terhadap buku suplemen 99 Fakta Budaya Indonesia diketahui melalui pemberian angket dan wawancara kepada mahasiswa di akhir pembelajaran. Hasil penilaian mahasiswa digunakan untuk melihat kelayakan dari materi ajar yang telah dikembangkan.

Tahun pertama dalam penelitian ini berfokus sampai pada tahap ketiga dalam pengembangan buku suplemen 99 Fakta Budaya Indonesia. Tahap implementasi produk dan evaluasi rencananya dilakukan pada tahun kedua penelitian ini. Hal ini didasarkan atas masukan dari reviewer yaitu Prof. Dr. Pujiati Suyata, M.Pd. dan pertimbangan akan produk yang dikembangkan agar lebih berkualitas.

Bagian-bagian lain seperti analisis data kualitatif, analisis data kuantitatif, revisi produk, kajian produk akhir, dan analisis kelayakan akan diselesaikan pada tahun kedua penelitian ini. Aspek-aspek kelayakan menjadi rumusan masalah utama yang akan dikembangkan. Analisis tersebut meliputi kelayakan isi, kelayakan bahasa, kelayakan 
Hermanto $^{1)^{*}}$, Sudaryanto ${ }^{2),}$ dan Cindy Febriana ${ }^{3),}$ : Pengembangan Buku Berbasis Ensiklopedia untuk Mata Kuliah Budaya Indonesia Program Darmasiswa Website:https://jurnal.umj.ac.id/index.php/penaliterasi Email:penaliterasi@umj.ac.id

penyajian, dan kelayakan kegrafikan akan menjadi bahan yang akan disempurnakan pada tahapan pengembangan selanjutnya.

\section{KESIMPULAN}

$\mathrm{K}$ esimpulan yang dapat dimunculkan dalam tulisan ini berupa tahapan dalam pengembangan buku berbasis Ensiklopedia dengan judul 99 Fakta Budaya Indonesia. Pertama, tahapan pengembangan buku berbasis ensiklopedia untuk mata kuliah budaya Indonesia. Adapun tahapan tersebut adalah sebagai berikut.

a. Deskripsi Hasil Tahap Analisis Kebutuhan Produk

Tahap analisis dimanfaatkan untuk memperoleh informasi terkait kebutuhan serta masalah yang melatarbelakangi dikembangkannya buku berbasis ensiklopedia untuk mata kuliah budaya Indonesia. Permasalahan yang diperoleh setelah melakukan observasi dan wawancara langsung di kelas Darmasiswa UAD mata kuliah Budaya Indonesia, peneliti memperoleh informasi bahwa pemelajar BIPA berasal dari beberapa negara yang memiliki budaya yang berbeda dengan Indonesia khususnya Yogyakarta, dan masih kurangnya minat membaca pemelajar BIPA, serta masih terbatasnya sumber belajar yang digunakan dalam pembelajaran BIPA yang hanya menggunakan buku Sahabatku Indonesia. Sehingga dengan temuan tersebut mengindikasikan minimnya sumber buku yang digunakan untuk pemelajar BIPA.

b. Deskripsi Tahap Desain

Setelah menganalisis kebutuhan produk berupa observasi dan wawancara, tahap selanjutnya adalah merencanakan pembuatan buku berbasis ensiklopedia untuk mata kuliah budaya Indonesia.

Adapun tahapan desain buku Ensiklopedia dengan judul Ensiklopedia Indonesia 99 Fakta Budaya Indonesia yaitu, 1) menentukan tema dan judul buku, 2) menyusun sistematika buku atau isiannya, dan 3) mengumpulkan bahan sebagai sumber informasi dan materi buku ensiklopedia.

c. Deskripsi Hasil Tahap Pengembangan

Mendesain buku ensiklopedia yang sudah dilakukan pada tahapan sebelumnya menjadi indikator untuk menyelesaikan bagian pengembangan buku tersebut. Pengembangan yang dilakukan adalah dengan mengembangkan dari rancangan berupa konten isi buku. Isi yang dimunculkan adalah seputar budaya dan informasi unik Indonesia. Desain yang menarik, gambar yang mencerminkan informasi tulisan menjadi ciri khas yang dimunculkan pada setiap nomor. Hal ini bertujuan untuk memudahkan dan membuat daya tarik pemelajar BIPA dalam memperoleh informasi. Tahapan selanjutnya adalah mengembangkan tulisan tersebut dengan mengajak penerbit buku K-Media yang beralamat di Banguntapan, Bantul Yogyakarta. Rencana tahun kedua adalah dengan memvalidasi buku tersebut kepada tiga orang ahli untuk menilai dan memberi masukkan terhadap buku ensiklopedia. Tahapan selanjutnya adalah deskripsi hasil tahap implementasi dan evaluasi akan dilakukan pada tahun kedua. 
Hermanto $^{1)^{*}}$, Sudaryanto ${ }^{2),}$ dan Cindy Febriana ${ }^{3),}$ : Pengembangan Buku Berbasis Ensiklopedia untuk Mata Kuliah Budaya Indonesia Program Darmasiswa

Website:https://jurnal.umj.ac.id/index.php/penaliterasi Email:penaliterasi@umj.ac.id

\section{UCAPAN TERIMA KASIH}

$\int \begin{aligned} & \text { capan terima kasih kepada Lembaga } \\ & \text { Penelitian dan Pengabdian } \\ & \text { Masyarakat Universitas Ahmad, }\end{aligned}$ Dahlan yang telah memfasilitasi dalam pengembangan penelitian, Kepala Kantor Urusan Internasional UAD yang sudah memberikan izin untuk tahap need assessment, dan mahasiswa program Darmasiswa tahun ajaran 2019/2020.

\section{REFERENSI}

Alwi, Hasan. 2008. Kamus Besar Bahasa Indonesia Edisi ke-3. Jakarta: Gramedia.

Brown, Dean James. 1995. The Element of Language Curiculum: A Syistematic Approach to Program Development. Boston: Heinle\&Heinle Publisher.

Chaer, Abdul. 2007. Leksikologi dan Leksikograsi Bahasa Indonesia. Jakarta: Rineka Cipta.

Harwood, Nigel. 2010. Issue in Material Development and Design, English Language Teaching Materials: Theory and Practice. London: Cambridge University.

Kemdiknas. 2008. Sosialisasi KTSP: Pengembangan Bahan Ajar. Jakarta: Kemdiknas.

Kusmiatun, Ari. 2015. Mengenal BIPA dan Pembelajarannya. Yogyakarta: KMedia.

Muliastuti, Liliana. 2017. Bahasa Indonesia bagi Penutur Asing Acuan Teori dan Pendekatan Pengajaran. Jakarta: Yayasan Pustaka Obor Indonesia.

Mulyana. 2003. Kurikulum Berbasis Kompetensi, Konsep, Karakteristik, dan Implementasi. Bandung: Remaja Rosdakarya.

Mulyatiningsih, Endang. 2011. Metode Penelitian Terapan Bidang Pendidikan. Bandung: Alfabeta.

Prasetiyo, Eko Andika. 2007. Pengembangan Bahan Ajar BIPA Bermuatan Budaya Jawa Bagi Penutur Asing Tingkat Pemula.

Siroj, Badrus Muhammad. 2015. Pengembangan Model Integratif Bahan Ajar Bahasa Indonesia Ranah Sosial Budaya Berbasis ICT Bagi Penutur Asing Tingkat Menengah. Jurnal Pendidikan Bahasa dan Sastra Indonesia FBS Unnes Vol. IV, edisi 1.

Suyitno, Imam. 2004. Pengetahuan Dasar BIPA (Pandangan Teoretis Belajar Bahasa). Yogyakarta: CV Grafika Indah.

Suyitno, Imam. 2005. Bahasa Indonesia untuk Penutur Asing (Teori, Strategi, dan Aplikasi Pembelajarannya). Yogyakarta: CV Grafika Indah 